\title{
REKAYASA BAHAN PELEDAK PADA STRUKTUR KOMPLEKS DI LITOLOGI LIMESTONE UNTUK OPTIMALISASI PERFORMANCE DALAM UPAYA MENURUNKAN BIAYA PENAMBANGAN
}

\author{
Teja Sukmara ${ }^{1)}$, Thomas Adi Putra ${ }^{2)}$, Muhammad Surya ${ }^{3)}$ \\ Divisi Tambang Umum ${ }^{1)}$, Divisi Kuari dan Konstruksi ${ }^{2)}$, Energetic Material Centre ${ }^{3)}$ \\ PT. Dahana (Persero)
}

\begin{abstract}
ABSTRAK
Limestone sebagai bahan utama pembuat semen adalah salah satu batuan sedimenter yang memiliki karakter struktur kompleks, berpori, dan fractury serta kadang dibeberapa tempat membentuk gua atau rongga yang cukup lebar. Sehingga dalam proses pemberaian batuan dengan menggunakan metode peledakan sering menjadi masalah dimana hasil dari fragmen peledakan masih terdapat boulder yang besar atau bahkan tidak bisa digali sama sekali oleh excavator karena adanya loose energy peledakan yang menyebabkan performance tidak optimal. Energetic Material Centre (EMC) di PT. Dahana (Persero) sebagai salah satu pusat pengembangan teknologi baik produk maupun aplikasi dalam kegiatan peledakan, telah merancang suatu jenis produk baru yang sesuai di kondisi struktur batuan limestone. Dengan density bahan peledak antara 0,7-0,8 gr/cc, komposisi jumlah kandungan Ammonium Nitrate yang lebih kecil sedangkan VOD yang dihasilkan yaitu antara $3.800 \mathrm{~m} / \mathrm{s}-4.250 \mathrm{~m} / \mathrm{s}$ (Sumber: Data Lab Rekayasa EMC PT. Dahana Persero) lebih besar dari VOD ANFO yaitu $3.000-3.500 \mathrm{~m} / \mathrm{s}$ dalam diameter 4,5 inch (Sumber: ISEE Blaster's Handbook $17^{\text {th }}$ Edition). Produk baru dengan brand Dawagel ini merupakan bahan peledak curah berbentuk gel yang sangat fleksibel terhadap rongga ataupun pori dalam lubang, sehingga mampu mengurangi effect decoupling dan setelah reaksi sempurna ikatan gel antar unsur sangat kuat sehingga akan tetap mempertahankan formasi dalam lubang atau tidak melebur kedalam rongga maupun celah seperti yang sering terjadi dengan bahan peledak cair lainnya. Hasil peledakan dengan menggunakan produk Dawagel di kuari PT. Semen Tonasa telah membuktikan performance hasil peledakan yang memuaskan. Fragmentasi yang dihasilkan adalah kurang dari 30 $\mathrm{cm}$ sebanyak $89,15 \%$, VOD produk hingga mencapai $4.128 \mathrm{~m} / \mathrm{s}$ pada diameter 4,5 inch. Secara keekonomisan telah berhasil mengurangi biaya peledakan sebesar IDR 114.000.000, - dalam 15 kali peledakan selama periode percobaan.
\end{abstract}

Kata Kunci: struktur kompleks, loose energy; Dawagel, ekonomis

\begin{abstract}
Limestone as the main material for making cement is one of the sedimentary rocks which has complex structures, porous, and fractur structural characteristics and sometimes in several places forms caves or cavities that are quite wide. So that in the process of rock dispersion using the blasting method is often raise a problem where the results of the blasting fragments are still large boulder or even cannot be excavated at all by the excavator because loose energy of explosives which causes the performance is not optimal. Energetic Material Centre (EMC) at PT. Dahana (Persero) as one of the technology developments canters both products and applications in blasting activities, has designed a new type of product that is suitable in limestone rock structure conditions. With explosive density between 0.7-0.8 gr / cc, the composition of the amount of Ammonium Nitrate content is smaller while the VOD produced is between $3,800 \mathrm{~m} / \mathrm{s}-4,250 \mathrm{~m} / \mathrm{s}$ (Source: EMC Engineering Lab Data of PT. Dahana Persero) is greater than VOD ANFO, which is 3,000 - 3,500 m/s in 4.5 inch diameter (Source: ISEE Blaster's Handbook 17th Edition). This new product with the brand is Dawagel, it is a bulk gel explosive which is very flexible to cavities or pores in the hole, so it can reduce the decoupling effect and after perfect reaction of the gel
\end{abstract}


bond between the elements is very strong so that it will maintain formation in the hole or not melted into the cavity or fissures as is often the case with other liquid explosives. The results of blasting using Dawagel products at PT. Semen Tonasa has proven satisfactory blasting performance. The resulting fragmentation was less than $30 \mathrm{~cm}$ as much as $89.15 \%$, the product $V O D$ reached $4,128 \mathrm{~m} / \mathrm{s}$ at a diameter of 4.5 inches. Economically it has succeeded in reducing blasting costs by IDR 114,000,000 in 15 blasting times during the trial period.

Keyword : struktur kompleks, loose energy; Dawagel, ekonomis

\section{A. LATAR BELAKANG MASALAH}

Batu gamping pada PT. Semen Tonasa memiliki tekstur batuan berongga, tak berongga, mudah lapuk dan tidak mudah lapuk, tingkat kekerasan atau memiliki nilai HGI berada pada rentang antara 60 -77 serta kandungan fosil yang berbeda-beda (Laraebi, Galid 2017). Sebuah penelitian yang dilakukan oleh M.E.J Wilson dan D.W.J. Bosense bisa menjelaskan gambaran strukur karstologi area Tonasa (Gambar 1). Limestone adalah batuan carbonate yang terbentuk dari proses evaporasi dan beberapa jenis batuan dari hasil evaporasi memiliki joint dan bedding plane (ISEE Blaster Handbook1 $8^{\text {th }}$ Edition).

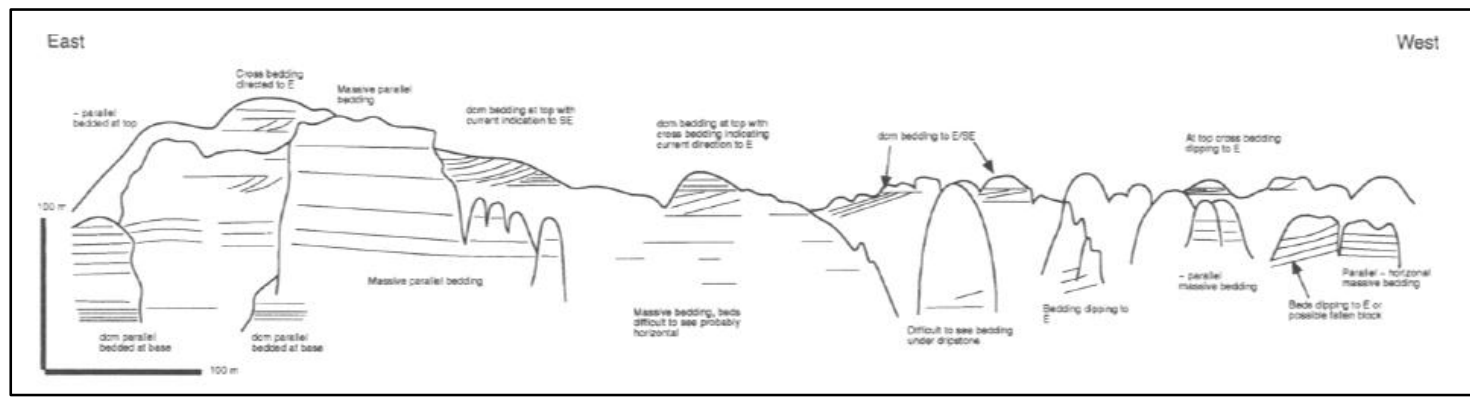

Gambar 1. Sketsa singkapan karstologi area Tonasa I (M E J Wilson \& D W J Bosense, 2016)

Struktur batu gamping di bagian atas (area development) dominan dalam kondisi lapuk dan struktur batuan yang lebih kompleks dibanding dengan bagian bawah, beberapa boulder batuan sendiri sudah terpisah dengan badan utama lapisan batu gamping, sehingga peledakan di bagian atas pit lebih sulit dalam penanganannya.

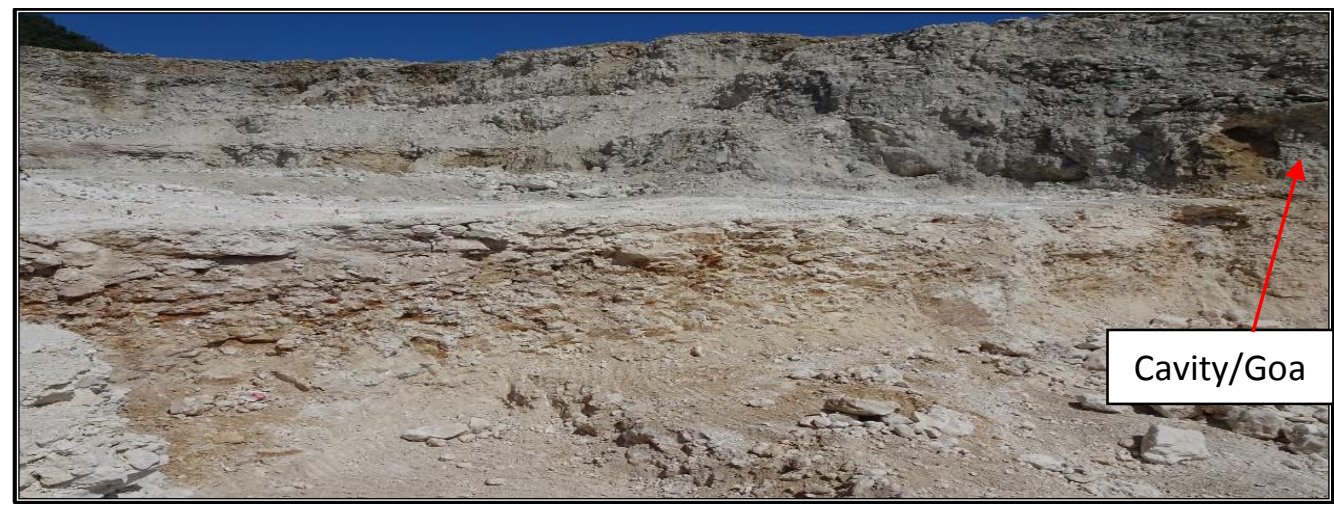

Gambar 2. Foto kuari PT. Semen Tonasa (Thomas A P, 2019)

Keberadaan air tanah tidak terlalu dominan terutama di bagian area development (Gambar 3) hanya saja area di bagian atas ini memiliki struktur yang paling kompleks (blocky). Sementara di bagian 
lapisan bawah kadang ditemukan lubang berair pada saat musim hujan dalam jumlah yang relative sedikit dan ketinggian air dari dasar lubang tidak terlalu dalam.

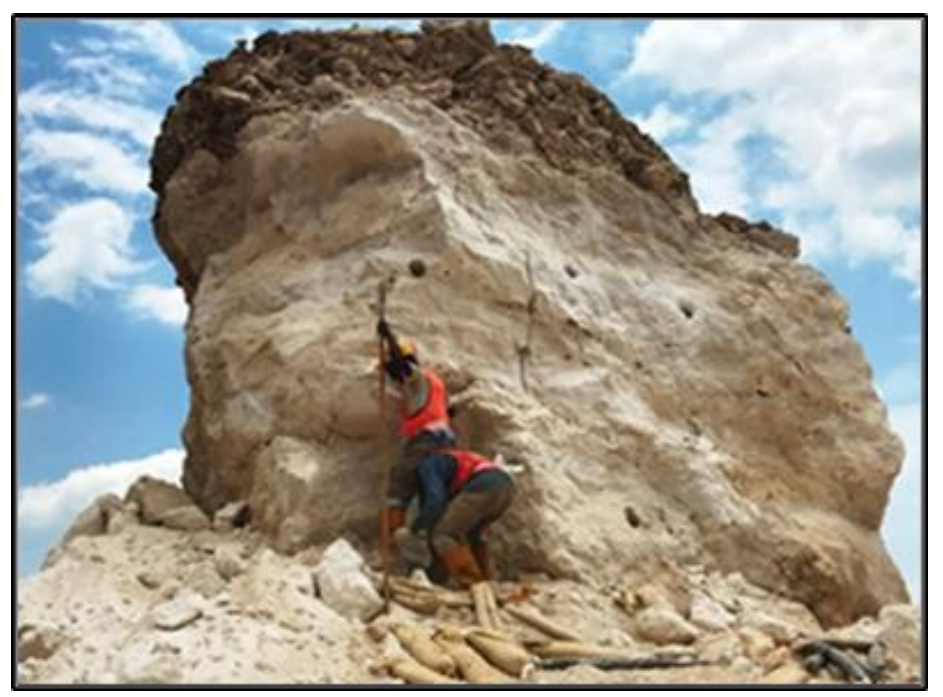

Gambar 3. Foto kegiatan charging bahan peledak di area development (Thomas A P, 2019)

Seringnya ditemui isian bahan peledak yang melorot di dasar lubang akibat adanya rongga atau goa walau sudah dilakukan pengisian bahan peledak utama sesuai rencana, maka akhirnya dibeberapa kali peledakan, bahan peledak utama lebih dulu dimasukkan dalam plastic liner (Gambar 4) sebelum dimasukkan ke dalam lubang. Dengan penerapan liner ini menuntut penanganan pekerjaan peledakan lebih lama dan semakin sulit mengingat dinding lubang dibeberapa bagian memiliki tekstur kasar/tajam dan bisa merobek lapisan plastik, dan disisi lain dengan penggunaan liner maka menurunkan energi bahan peledak akibat efek decoupling.

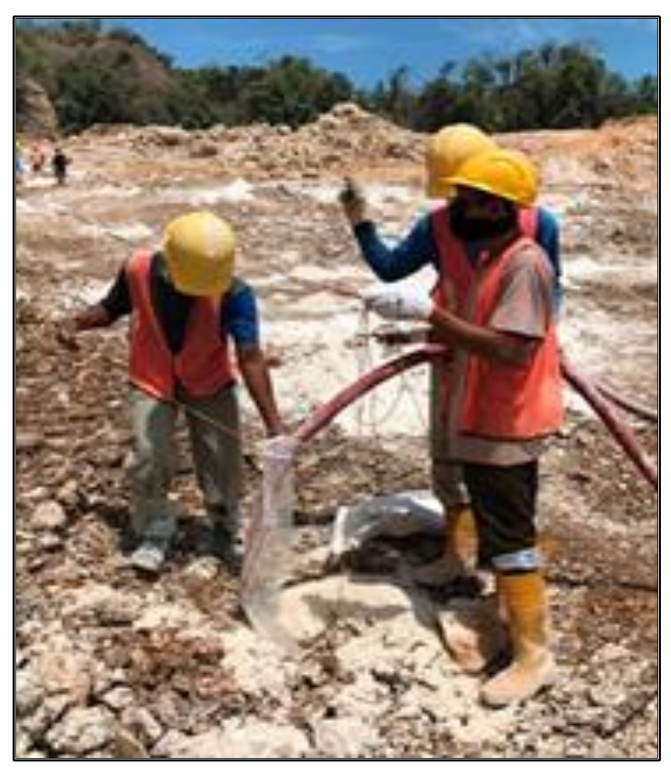

Gambar 4. Foto kegiatan charging emulsion dengan menggunakan plastik liner didalam lubang berongga (Thomas A P, 2019)

Bertambah sulit lagi pada beberapa tempat terdapat goa (cavity) seperti terlihat dalam Gambar 2, sehingga berdampak terhadap hasil peledakan yang sangat buruk dengan masih dihasilkannya boulder batu yang berukuran besar (Gambar 5). 


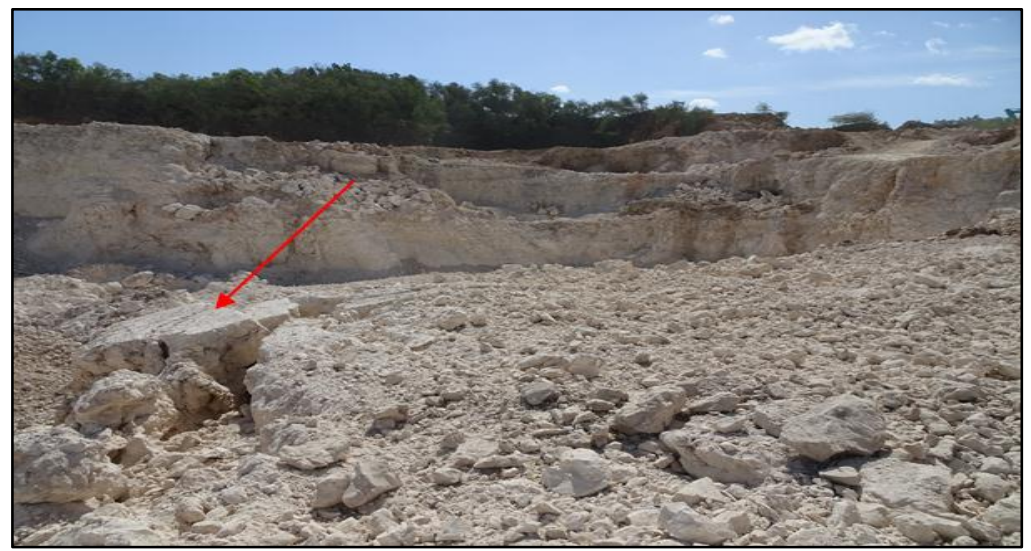

Gambar 5. Boulder hasil peledakan dimana terdapat goa di bawah lokasi peledakan

\section{B. LATAR BELAKANG PEMILIHAN LOKASI}

Penelitian di lakukan di salah satu kuari milik PT. Semen Tonasa yang berada di daerah Biring Ere, Bungoro Pangkajene Provinsi Sulawesi Selatan (Gambar 6). Dimana pabrik pengolahan material batu gamping menjadi produk semen portland yang masih dioperasikan adalah sebanyak 4 unit. Perusahaan ini merupakan salah satu anak perusahaan dari PT. Semen Indonesia yang merupakan pemasok sekitar 40,8 \% pasar domestik di Indonesia. Dalam upaya untuk penurunan biaya operasi terutama dalam hal konsumsi energi yang merupakan $41 \%$ beban pokok produksi maka beberapa langkah strategis di hulu sampai hilir terus diupayakan (Sumber: Laporan Berkelanjutan 2017; PT. Semen Indonesia).

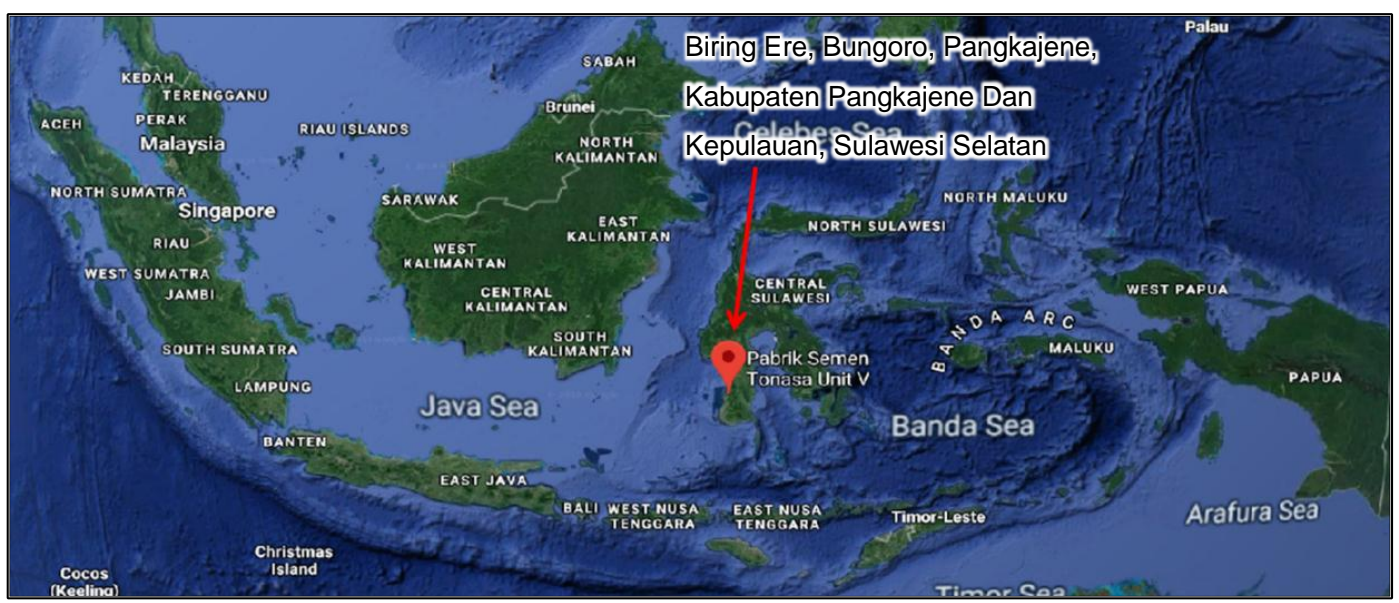

Gambar 6. Lokasi penelitian di PT Semen Tonasa

Dasar pemilihan lokasi ini dengan beberapa pertimbangan sbb:

- Komitmen berkesinambungan PT. Dahana (Persero) untuk selalu dapat memberikan nilai tambah ke operasi penambangan.

- Dabex 73C merupakan inovasi yang akan diaplikasikan kali pertama di Semen Indonesia Group.

- Menjawab tantangan kesulitan penambangan di area development saat ini berupa kondisi geologi batuan berongga di B8 \& B9.

- Pertimbangan aspek safety dan dampak blasting ke community (minimalisasi potensi flying rock).

- Efisiensi dan optimalisasi pemakaian handak di area development produksi (minimalisasi lose handak dan overcharge di area development). 
- Optimalisasi hasil peledakan di area development (akibat decoupling effect dari pemakaian liner).

- Efesiensi waktu proses peledakan dilokasi development (pemakaian unit mekanis untuk charging/tidak lagi sistem manual)

- Akselerasi pencapaian target produksi dan kemajuan tambang.

- Efesiensi personil peledakan dilokasi peledakan.

\section{PROSES DESAIN AWAL BAHAN PELEDAK}

Kondisi geologi adalah faktor dominan yang menentukan performance peledakan (ISEE Blaster Handbook $18^{\text {th }}$ Edition), sehingga hal ini cukup kuat menjadi dasar dalam rekayasa bahan peledak sebagai salah satu acuan pendekatan untuk mengatasi kondisi geologi tertentu agar bisa tetap menjaga performansi hasil secara optimal.

Strukur batuan limestone yang berongga, dan dibeberapa tempat memiliki rekah yang cukup rapat sehingga hal ini akan berdampak terhadap produk bahan peledak curah, baik berbentuk padatan prill atau cairan, menjadi sensitif terhadap terjadinya peluruhan yang berakibat turunnya tinggi kolom isi bahkan kadangkala ditemukan beberapa kasus bahan sampai tenggelam ke bagian bawah dari lubang.

Bahan peledak ANFO merupakan jenis bahan peledak padatan yang berupa butiran halus dengan diameter antara 1-2 mm, ketika menghadapai kondisi batuan yang memiliki rekahan maka seiring waktu bahan tersebut akan terus turun mengisi celah-celah dan ruang kosong dari batuan karena antar butiran tidak ada media yang mengikat menjadi suatu kesatuan. Produk Dabex 73 merupakan campuran antara emulsion dengan ANFO, dalam campuran ini butiran ANFO sudah diikat oleh media emulsion menjadi suatu kesatuan, hanya saja karena emulsion ini berupa fasa cairan dengan viskositas tertentu sehingga ketika menemui rekahan atau rongga dalam batuan yang lebih besar maka akan tenggelam kebawah lubang sama hal dengan ANFO.

Kecenderungan perilaku kedua jenis bahan peledak curah diatas pada akhirnya menjadi acuan awal dalam penentuan karakter jenis bahan peledak yang akan dikembangkan, yatu mengkombinasi bahan peledak padatan prill dengan diikat oleh media cair/gel yang lebih solid dan bisa mempertahankan formasi awal sehingga akan meminimalkan terjadinya peluruhan kedalam rongga atau rekahan batuan.

\section{REKAYASA PRODUK BAHAN PELEDAK}

Energetic Material Centre sebagai salah satu pusat pengembangan bahan peledak membuat sebuah formulasi bahan peledak fasa cair/gel sebagai media pengikat bahan yang nantinya akan dicampur dengan ANFO. Proses rekayasa dilakukan melalui tahapan sesuai Prosedur Perancangan dan Pengembangan Nomor: DHN-2.6-RND-PR.034 dalam Integrated System SIMADA.

Formulasi awal dilakukan di Laboratorium Rekayasa dengan mencoba komposisi dalam skala laboratorium dan dilanjutkan dengan pengujian kriteria-kriteria mutu yang diharapkan. Proses rekayasa di laboratorium selain untuk mengembangkan komposisi kimia yang tepat adalah untuk menentukan proses aplikasi produksi bahan dalam skala lab dan uji stabilitas produk baik secara kimia maupun fisika (Gambar 7) dan dari hasil proses rekayasa ini maka telah dihasilkan produk baru yang diberi merk Dawagel atau similar dengan Dabex 73C. 


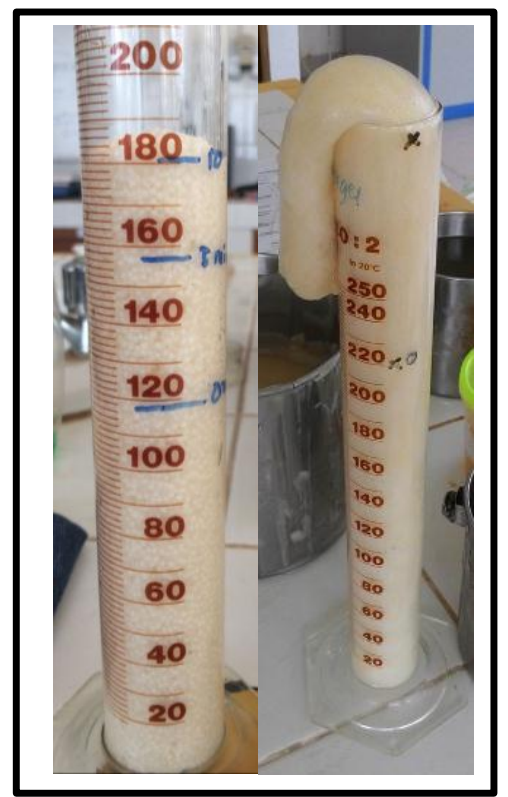

Gambar 7. Proses pengujian density bahan peledak dalam tabung reaksi

Cross linker yang menjadi kunci diferensiasi produk ini terhadap kemampuan dalam mempertahankan formasi atau bentuk jika dibandingkan dengan produk bahan peledak fasa cair lainnya. Dawagel sebagai produk yang memiliki keunggulan dalam mempertahankan bentuk/formasi setelah proses pencampuran semua bahan kimia baik sensitizer ataupun cross link di laboratorium telah dibuktikan bahwa produk tersebut bisa secara konsisten dalam mempertahankan bentuk meskipun produk sudah dikeluarkan dari tabung reaksi (Gambar 8).

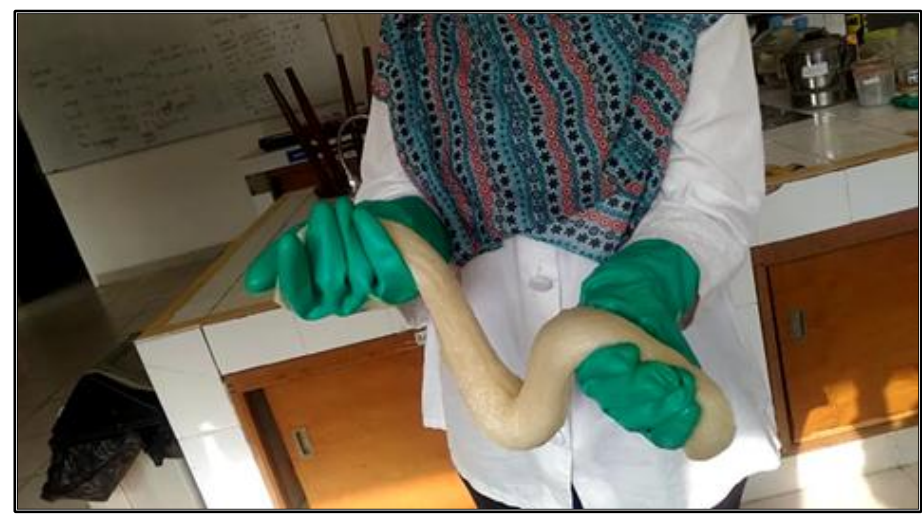

Gambar 8. Produk Dawagel hasil rekayasa laboratorium yang memperlihatkan kemampuan bahan peledak fasa cair dalam mempertahankan formasi setelah proses pencampuran semua bahan

Hasi uji laboratorium menunjukkan kestabilan viskositas produk pada rentang waktu 1 bulan (Gambar 9) sudah cukup aman dalam rentang baku mutu yaitu diantara $26.000-29.000 \mathrm{cP}$ dan pengembangan produk dengan indikator density sudah sesuai kriteria acuan dalam prosedur antara $0,6-0,8 \mathrm{gr} / \mathrm{cc}$ (Gambar 10) . 


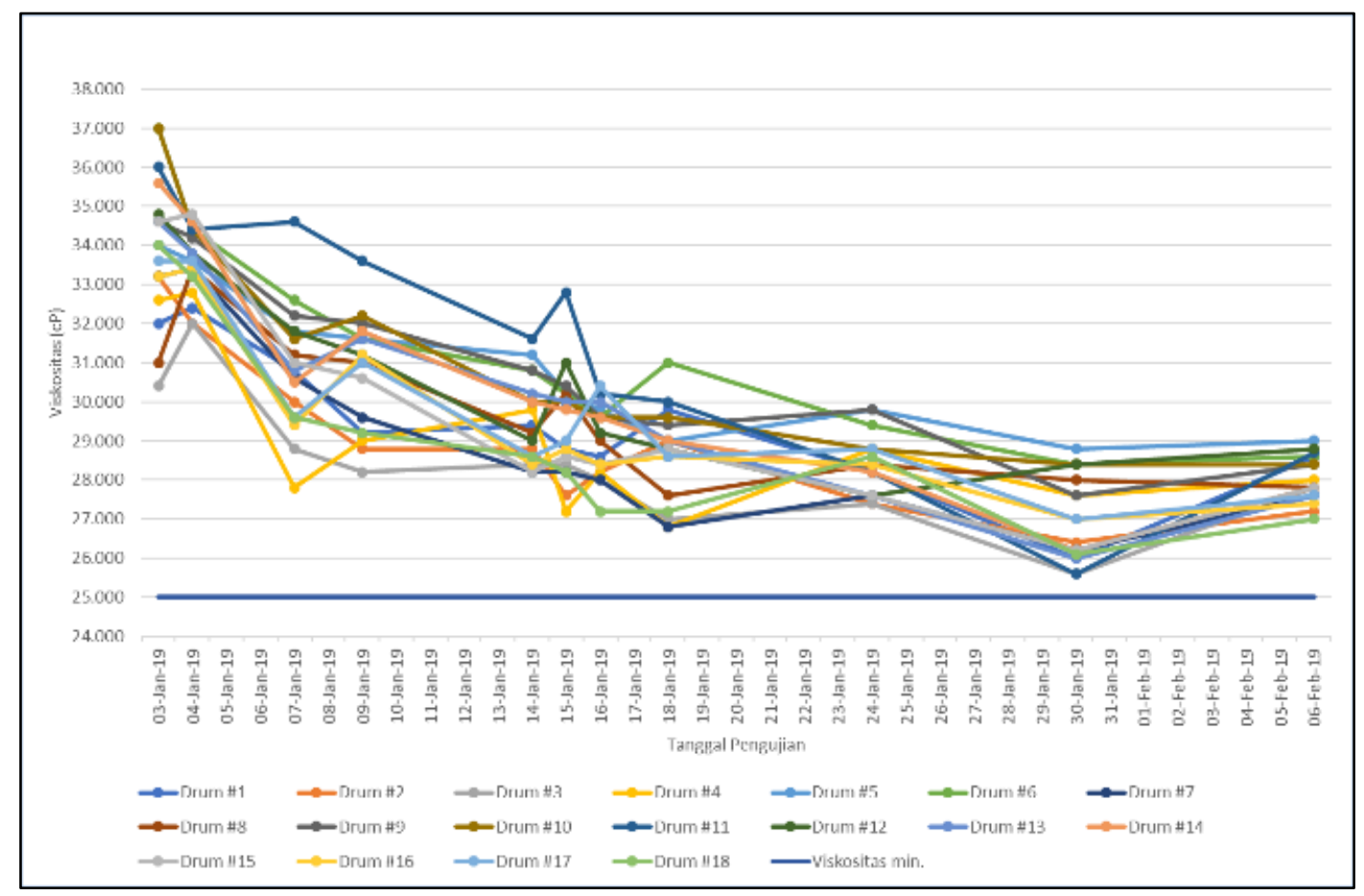

Gambar 9. Grafik hasil uji viskositas dalam 1 bulan

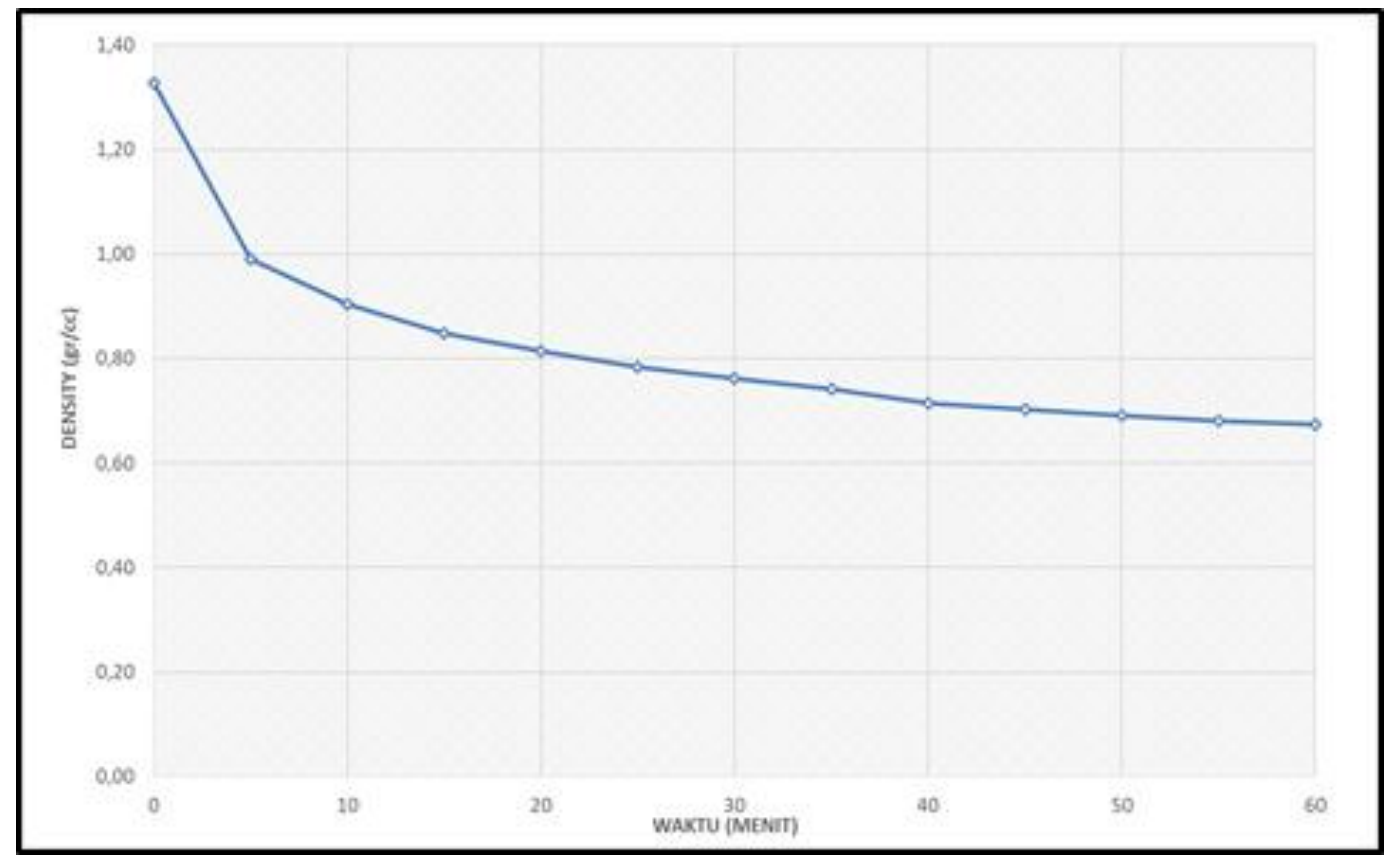

Gambar 10. Grafik hasil uji density produk dalam rentang waktu 1 jam

\section{E. UJI LEDAK SKALA LABORATORIUM}

Ketika semua kriteria baku mutu produk sudah terpenuhi, maka proses pembuktian kualitas energi harus dilakukan dengan melakukan uji ledak di dalam area pengujian yang khusus disediakan. Dan dari beberapa kali pengujian akhirnya bisa ditemukan korelasi optimal antara parameter mutu produk terhadap energi yang tepat sesuai harapan. 


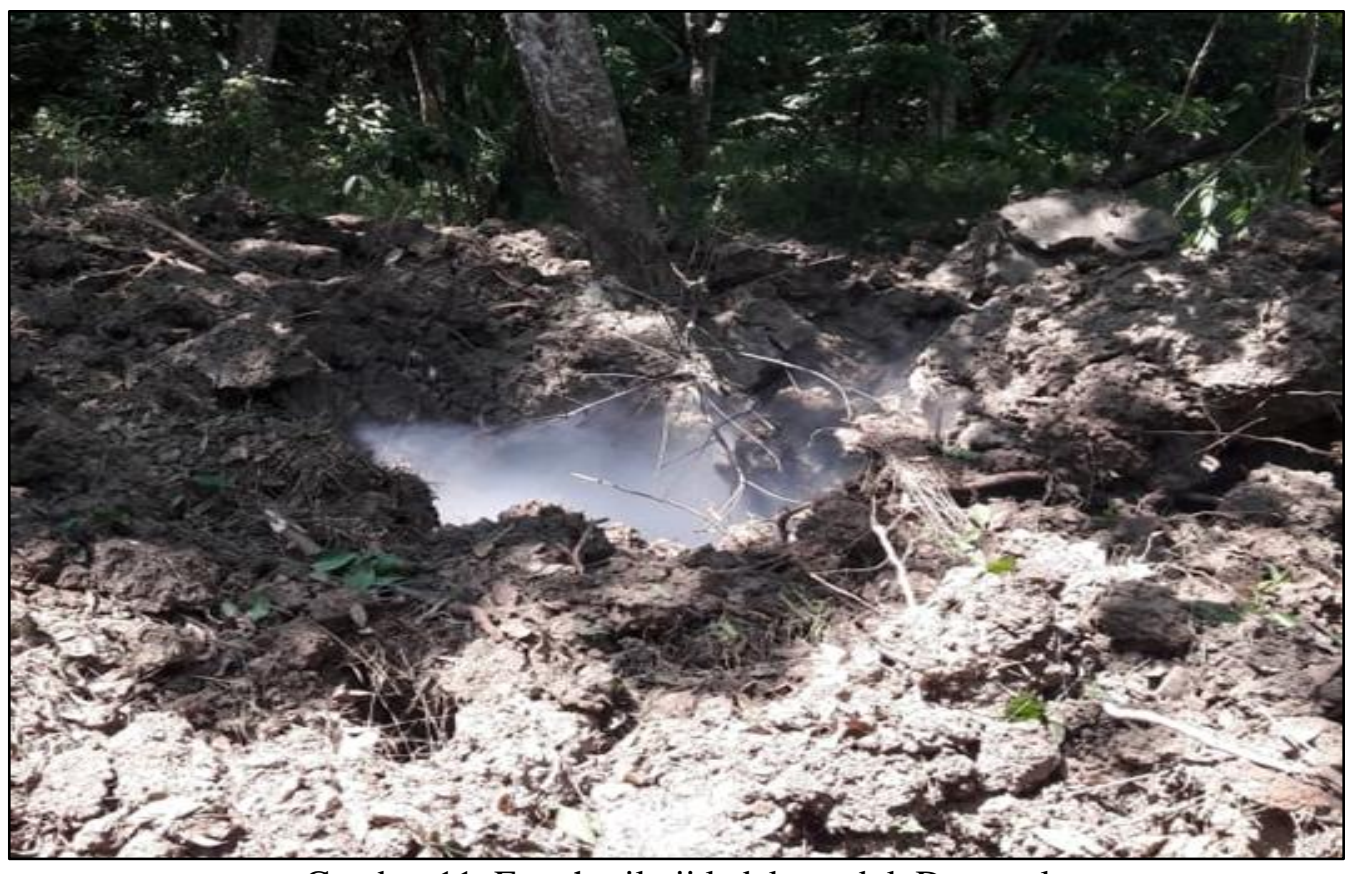

Gambar 11. Foto hasil uji ledak produk Dawagel

Hasil uji coba peledakan dengan berbagai kondisi viskositas bahan telah berhasil menemukan kondisi viskositas dengan VOD yang konsisten pada rentang $4.100-4.300 \mathrm{~m} / \mathrm{s}$ (Gambar 12). Sesuai acuan baku mutu maka nilai VOD yang diharapkan sudah memenuhi standar.

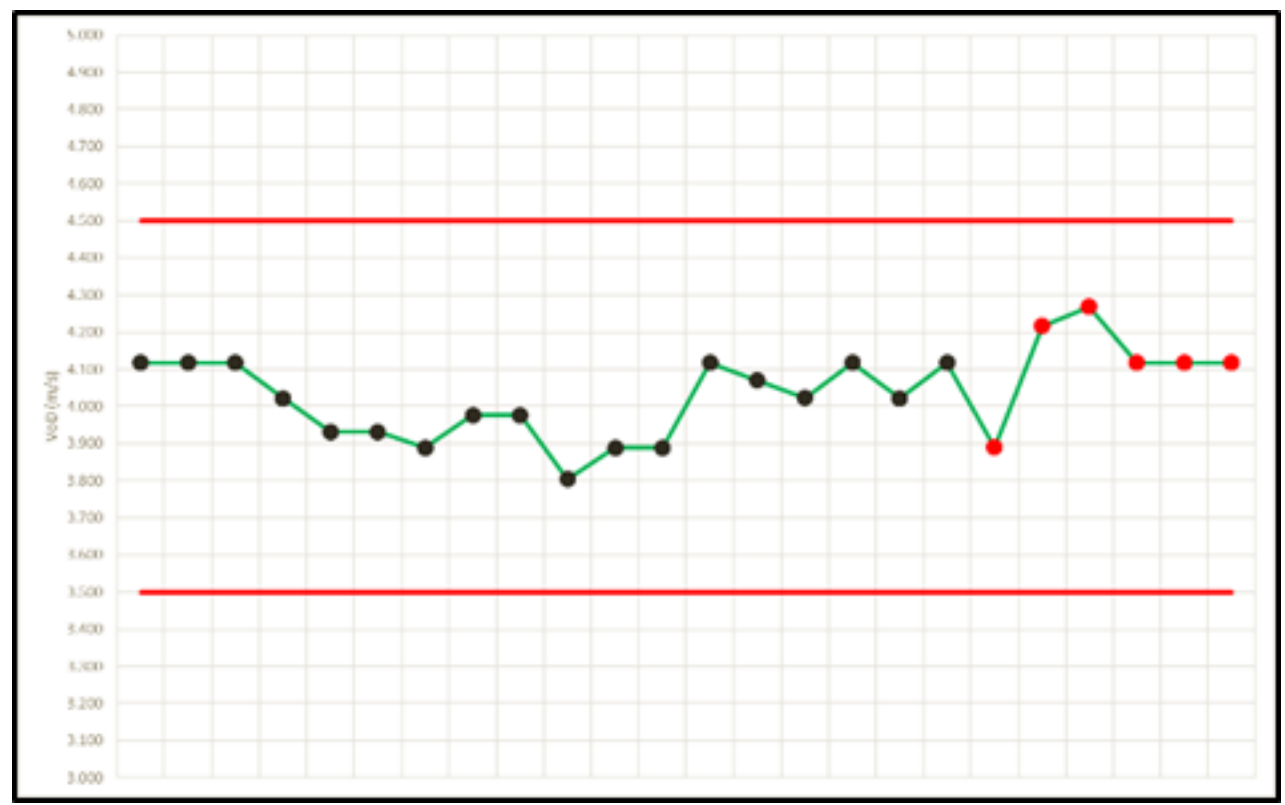

Gambar 12. Hasil pengukuran VOD produk Dawagel

\section{F. REKAYASA PROSES PRODUKSI OSP DAN APLIKASI MMT}

Proses produksi pembuatan produk baru ini di desain agar bisa dilakukan di On-Site Plant (OSP) yang sudah existing. Dimana dengan adanya produk baru sistem produksi existing tidak memerlukan penambahan tool atau equipment, hanya diperlukan modifikasi proses saja, namun secara umum sudah sangat compatible. 
Pencampuran bahan peledak yang menggunakan Mobile Mixing Truck (MMT) karena ada penambahan chemical khusus untuk proses peningkatan sensitifitas dan penguatan ikatan bahan peledak cair agar terhindar dari proses deformasi yang menerus maka product mengharuskan penambahan satu kompartemen dan fluida pompa yang dipasang ke unit MMT.

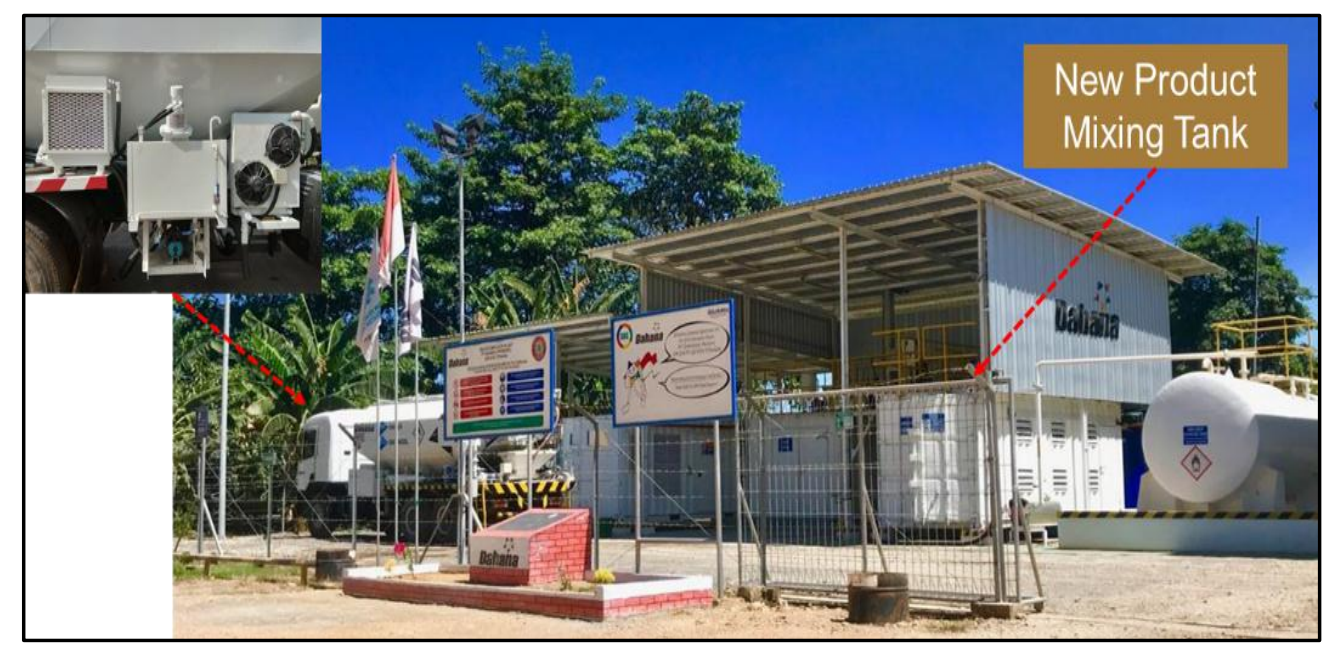

Gambar 13. Modifikasi MMT dan fasilitas OSP untuk Dawagel

\section{G. APLIKASI DAWAGEL DI PELEDAKAN KUARI LIMESTONE}

Aplikasi existing ANFO digunakan di zona lapisan atas (area development) ketika lokasi lebih dekat ke permukaan dimana lebih banyak potensi struktur dan cavity. Dan penggunaan Dabex 73 di aplikasikan di zona yang lebih aman struktur dan berair pada saat musim hujan. Geometri peledakan yang biasa dilakukan adalah:

- Diameter =4,5 inch

- Kedalaman $\quad=9-11 \mathrm{~m}$

- Burden $=4 \mathrm{~m}$

- Spacing =5 m

- Stemming = $1,75-2 \mathrm{~m}$

- Isian Handak ANFO $\quad=60-85 \mathrm{Kg}$

- Isian Handak Dabex $\quad=80-120 \mathrm{Kg}$

- Jenis Bahan Peledak = ANFO dan Dabex

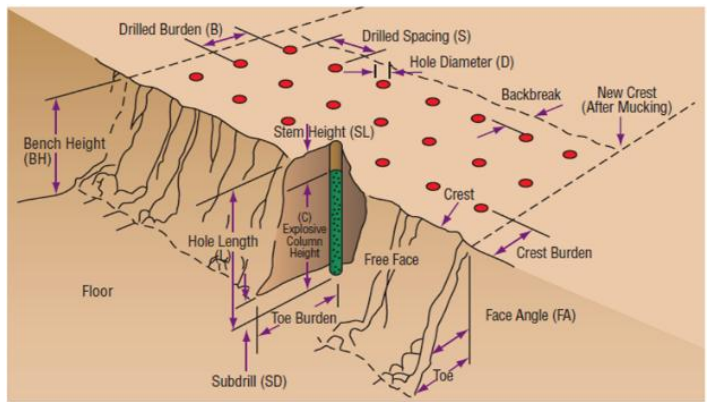

Gambar 14. Data dan desain geometri peledakan

Aplikasi produk Dawagel tidak mengharuskan adanya perubahan geometri sehingga analisa dilakukan adalah terhadap kondisi yang sama. Proses pengendalian mutu produk dilapangan penerapannya sama dengan produk Dabex 73 yang sudah biasa diterapkan dilokasi penelitian. Density produk yang terukur pada saat awal charging adalah antara 1,1-1,3 gr/cc dan setelah proses pengembangan dalam kurun waktu sekitar 15 menit diperoleh density sensitif produk antara $0,72-$ $0,85 \mathrm{gr} / \mathrm{cc}$. 


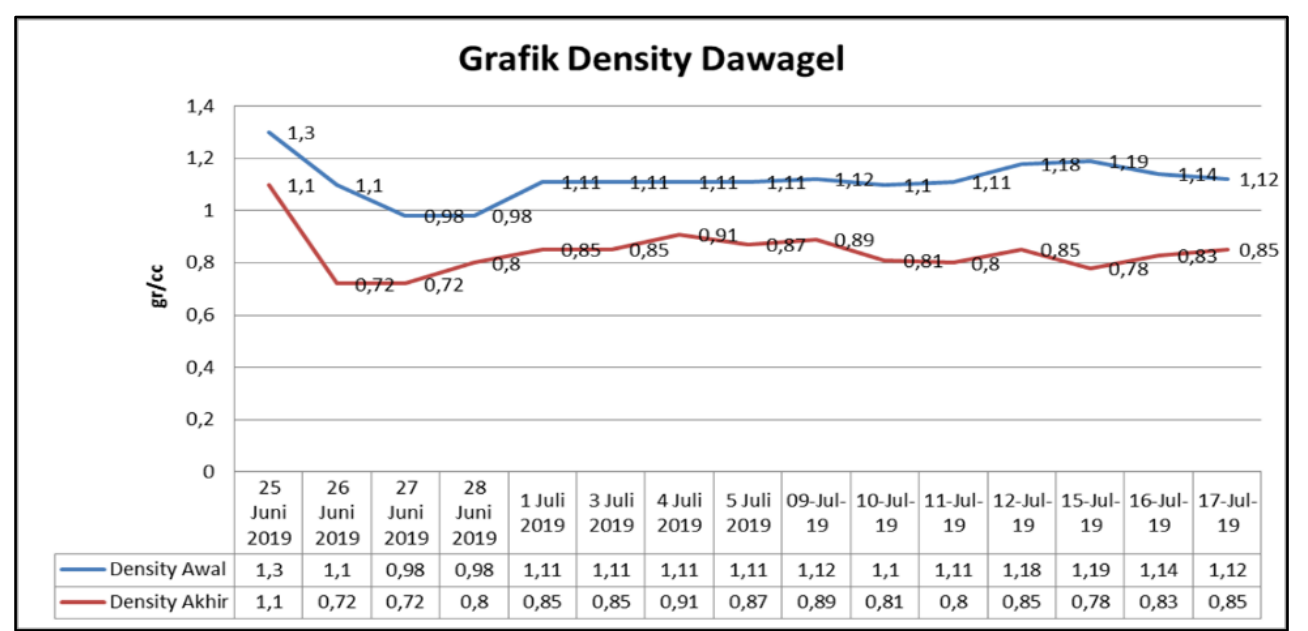

Gambar 15. Aktivitas pengendalian kualitas produk dan grafik hasil pengujian pada saat charging di lokasi peledakan

Setelah parameter kualitas pada persiapan peledakan memenuhi baku mutu maka pengamatan selanjutya adalah untuk mengukur VOD pada setiap event peledakan. Hal ini sebagai parameter performance secara aktual daripada produk baru dalam kondisi aplikasi secara real pada lubang ledak yang mana hal ini juga dipengaruhi oleh kondisi batuan.

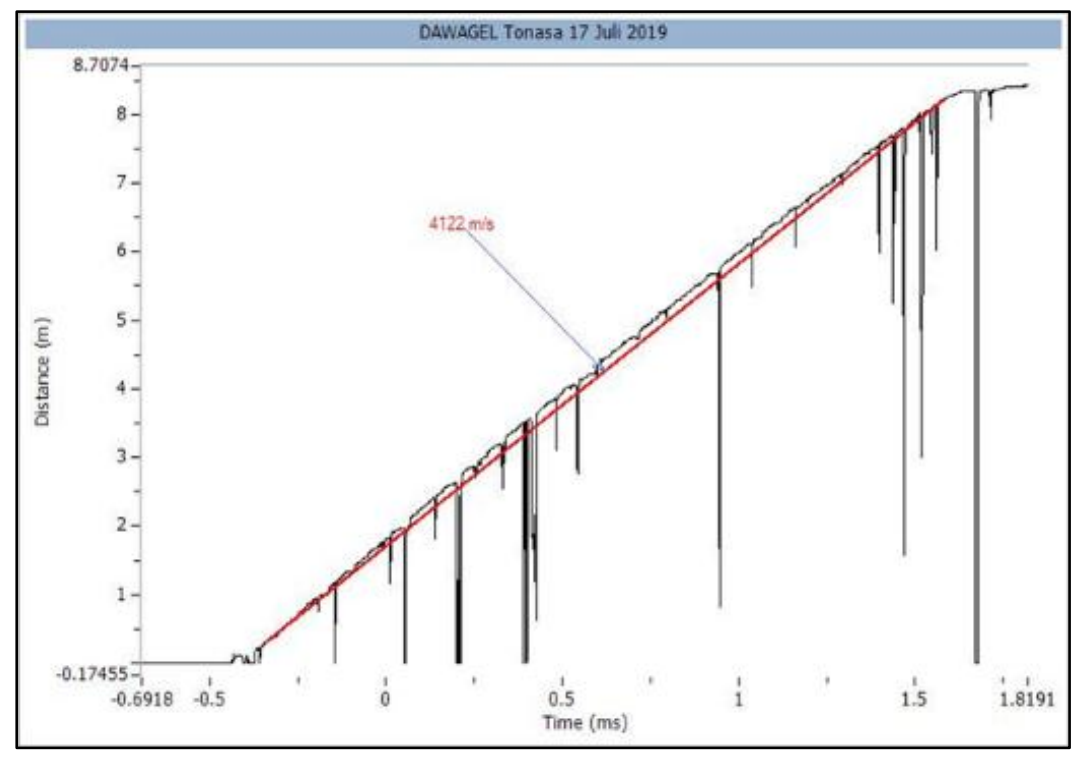

Gambar 16. Kegiatan pengukuran dan grafik hasil pengukuran VOD

Hasil pengukuran VOD menunjukkan hasil yang sudah memenuhi baku mutu pada beberapa kali percobaan dimana salah satu pengukuran pada tanggal 17 Juli 2019 diperoleh nilai VOD sebesar $4.122 \mathrm{~m} / \mathrm{s}$. Adapun data detail beberapa kali uji VOD seperti tabel dibawah:

Tabel 1. Data hasil pengukuran VOD produk Dawagel (Dabex 73C)

\begin{tabular}{|c|c|c|c|}
\hline No & Tanggal & Lokasi & $\begin{array}{l}\text { VOD } \\
\mathrm{m} / \mathrm{s}\end{array}$ \\
\hline 1 & $27 / 06 / 2019$ & B8 & 3.916 \\
\hline 2 & $28 / 06 / 2019$ & B4 Utara & 4.035 \\
\hline 3 & $01 / 07 / 2019$ & B8 Utara & 4.128 \\
\hline 4 & $11 / 07 / 2019$ & B4 Selatan & 3.948 \\
\hline 5 & $16 / 07 / 2019$ & B5 Barat & 3.669 \\
\hline 6 & $17 / 07 / 2019$ & B4 & 4.122 \\
\hline
\end{tabular}




\section{H. FRAGMENTASI PELEDAKAN PADA APLIKASI DAWAGEL}

Fragmentasi hasil peledakan adalah sebagai indikator terhadap kinerja produk dan aplikasi peledakan yang diterapkan sudah baik atau tidak, maka dari beberapa kali peledakan dengan produk baru diperoleh hasil fragmentasi yang sudah sesuai harapan.

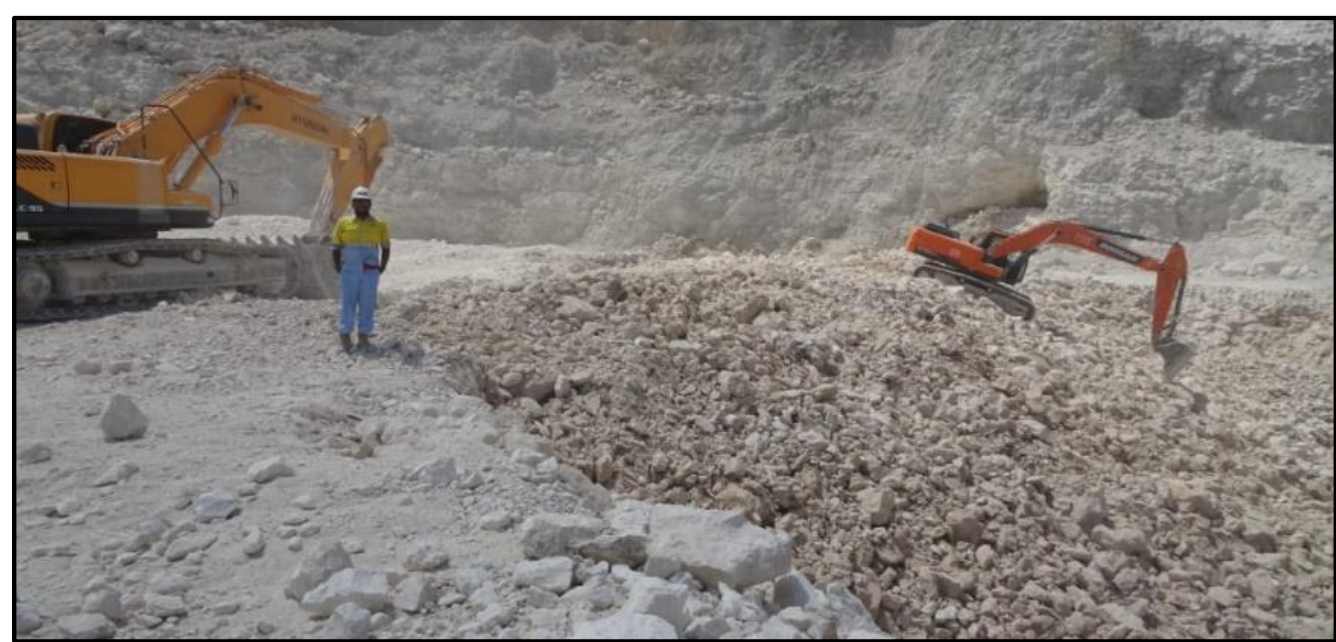

Gambar 17. Fragmentasi hasil peledakan dengan menggunakan isian utama Dawagel

Analisa fragmentasi menggunakan objek gambar, dengan parameter penggambaran (delineation parameters) scala informasi 36.753 pixel/unit, yang dihasilkan dari maksimum 40 partikel dengan texture ratio 1.1, single object.

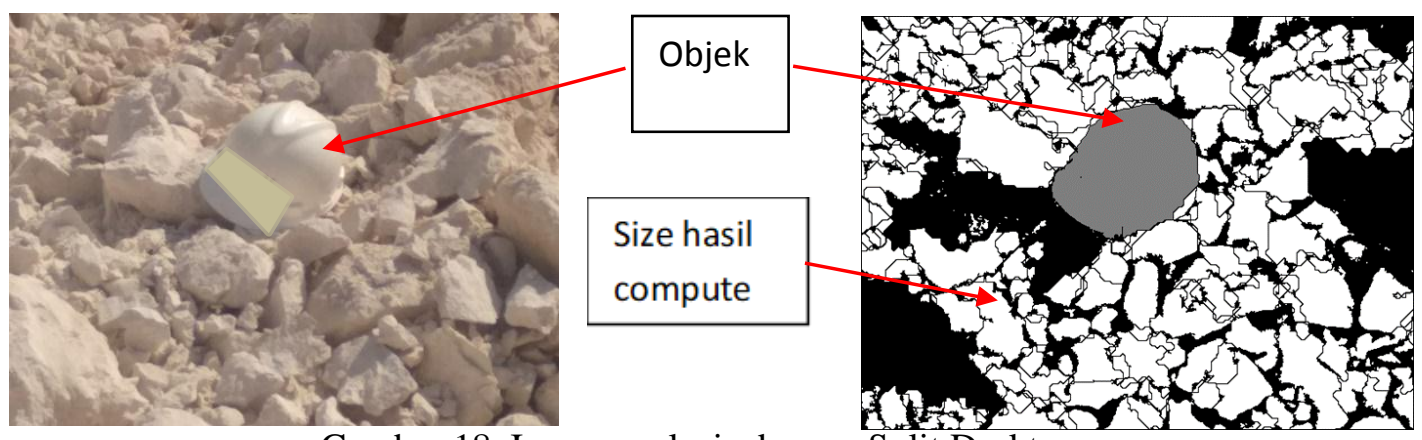

Gambar 18. Image analysis dengan Split Desktop

Untuk penyesuaian persentase pada objek sekitar 50\% dipakai menggunakan metoda schuhmann. Merupakan gambar yang dihasilkan pada metoda tersebut, dimana partikel yang dihasilkan mewakili besarnya ukuran yang dihasilkan dengan size fragmentasi rata-rata (P50) di 9,63 cm dan maksimum size di $63 \mathrm{~cm}$.

\section{CRUSHER FACTOR HASIL PELEDAKAN}

Kondisi penggunaan bahan peledak apabila hanya menggunakan single produk (Dabex 73), untuk Crusher Factor (CF) rerata: 0,19 kg/ton (Handak Batu kapur), setara dengan Powder factor (PF): $0,44 \mathrm{~kg} / \mathrm{bcm}$ (handak batu kapur). 


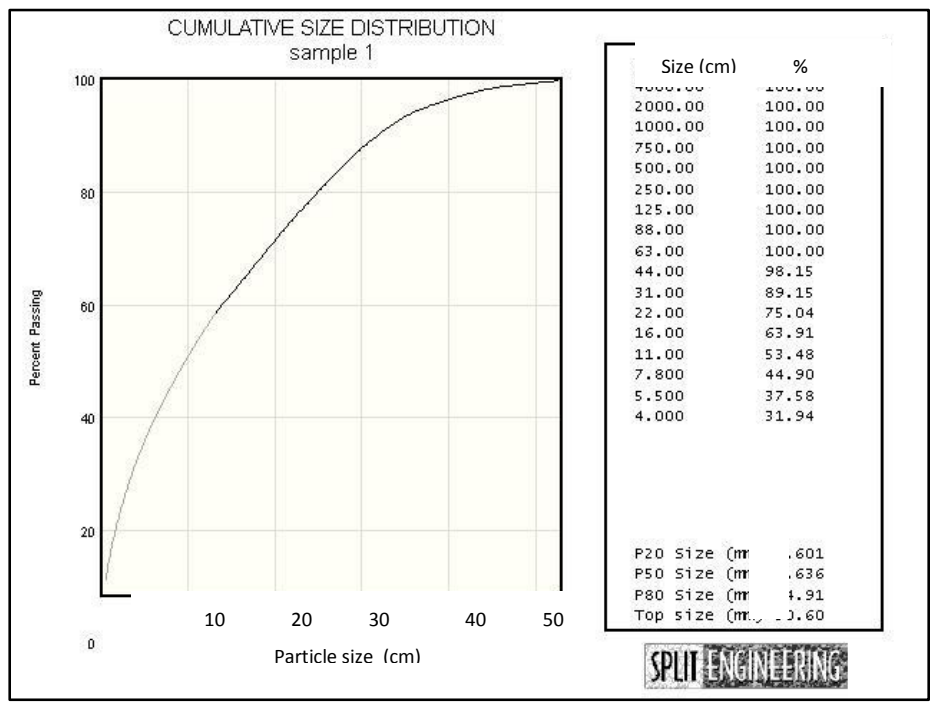

Gambar 19. Grafik hasil analisa fragmentasi

Tabel 2. Data estimasi peledakan tanpa Dawagel

\begin{tabular}{|c|c|c|c|c|c|c|c|c|c|c|}
\hline \multirow[b]{2}{*}{ No } & \multirow[b]{2}{*}{ Tanggal } & \multirow[b]{2}{*}{ Lokasi } & \multicolumn{3}{|c|}{ Geometri } & \multirow{2}{*}{$\begin{array}{c}\text { Dabex } \\
73 \\
(\mathrm{KG})\end{array}$} & \multirow[b]{2}{*}{$\begin{array}{l}\text { Volume } \\
\text { (BCM) }\end{array}$} & \multirow{2}{*}{$\begin{array}{c}\text { Tonage } \\
\text { Rock Density } 2,3 \mathrm{gr} / \mathrm{cc} \\
(\mathrm{TON}))\end{array}$} & \multirow[b]{2}{*}{$\begin{array}{c}\mathrm{PF} \\
\mathrm{KG} / \mathrm{BCM}\end{array}$} & \multirow[b]{2}{*}{$\begin{array}{c}\mathrm{CF} \\
\mathrm{KG} / \mathrm{TON}\end{array}$} \\
\hline & & & $\begin{array}{c}\text { Burden } \\
\text { (M) }\end{array}$ & $\begin{array}{l}\text { Spacing } \\
\text { (M) }\end{array}$ & $\begin{array}{c}\text { Kedalaman } \\
\text { (M) }\end{array}$ & & & & & \\
\hline 1 & $25 / 06 / 2019$ & B4 & 4 & 6 & 12,0 & 7.017 & 17.280 & 39.744 & 0,41 & 0,18 \\
\hline 2 & $26 / 06 / 2019$ & B4 & 3 & 4 & 8,0 & 1.083 & 1.536 & 3.533 & 0,71 & 0,31 \\
\hline 3 & $27 / 06 / 2019$ & B8 & 4 & 5 & 5,5 & 4.739 & 12.100 & 27.830 & 0,39 & 0,17 \\
\hline 4 & $28 / 06 / 2019$ & B4 Utara & 4 & 6 & 10,5 & 4.136 & 10.584 & 24.343 & 0,39 & 0,17 \\
\hline 5 & $01 / 07 / 2019$ & B8 Utara & 4 & 5 & 6,0 & 6.155 & 15.000 & 34.500 & 0,41 & 0,18 \\
\hline 6 & 03/07/2019 & B4 Tengah & 4 & 6 & 11,0 & 4.918 & 12.408 & 28.538 & 0,40 & 0,17 \\
\hline 7 & $04 / 07 / 2019$ & B5 Tengah & 4 & 6 & 11,0 & 8.266 & 20.856 & 47.969 & 0,40 & 0,17 \\
\hline 8 & 05/07/2019 & B4 Tengah & 4 & 6 & 11,0 & 7.534 & 19.008 & 43.718 & 0,40 & 0,17 \\
\hline 9 & 09/07/2019 & B8 & 4 & 6 & 11,0 & 5.232 & 13.200 & 30.360 & 0,40 & 0,17 \\
\hline 10 & $10 / 07 / 2019$ & B4 Timur & 4 & 6 & 10,5 & 5.909 & 15.120 & 34.776 & 0,39 & 0,17 \\
\hline 11 & $11 / 07 / 2019$ & B4 Selatan & 4 & 6 & 11,3 & 6.165 & 15.440 & 35.512 & 0,40 & 0,17 \\
\hline 12 & $12 / 07 / 2019$ & B4 Tengah & 4 & 6 & 10,4 & 4.577 & 11.743 & 27.009 & 0,39 & 0,17 \\
\hline 13 & 15/07/2019 & B4 Utara & 4 & 6 & 12,0 & 7.368 & 18.144 & 41.731 & 0,41 & 0,18 \\
\hline 14 & $16 / 07 / 2019$ & B5 Barat & 3 & 4 & 6,0 & 3.939 & 5.760 & 13.248 & 0,68 & 0,30 \\
\hline 15 & $17 / 07 / 2019$ & B4 & 4 & 6 & 12,0 & 10.525 & 25.920 & 59.616 & 0,41 & 0,18 \\
\hline & & To & & & & 87.563 & 214.099 & 492.427 & 0,44 & 0,19 \\
\hline
\end{tabular}

Namun ketika penggunaan 2 (dua) Produk yaitu Dawagel \& Dabex 73, dilihat dari tabel diatas terjadi penurunan Crusher Factor $(\mathrm{CF})$ dari sebelumnya $0,19 \mathrm{~kg} / \mathrm{ton}$ (handak batu kapur) menjadi $0,17 \mathrm{~kg} /$ ton setara dengan PF $0,39 \mathrm{Kg} / \mathrm{Bcm}$. 
Tabel 3. Data aktual aplikasi peledakan dengan kombinasi Dawagel

\begin{tabular}{|c|c|c|c|c|c|c|c|c|c|c|c|}
\hline \multirow[b]{2}{*}{ No } & \multirow[b]{2}{*}{ Tanggal } & \multirow[b]{2}{*}{ Lokasi } & \multicolumn{3}{|c|}{ Geometri } & \multicolumn{2}{|c|}{ Hole } & \multirow{2}{*}{$\begin{array}{c}\text { Dabex } 73 \\
+ \\
\text { Dawagel } \\
(\mathrm{KG})\end{array}$} & \multirow{2}{*}{\multicolumn{2}{|c|}{$\begin{array}{c}\text { Tonage } \\
\text { Rock Density } 2,3 \\
\text { gr/cc } \\
(\mathrm{TON}))\end{array}$}} & \multirow[b]{2}{*}{$\begin{array}{c}\text { PF } \\
\text { KG/BCM } \\
\end{array}$} \\
\hline & & & $\begin{array}{c}\text { Burden } \\
\text { (M) }\end{array}$ & $\begin{array}{c}\text { Spacing } \\
(\mathrm{M}) \\
\end{array}$ & $\begin{array}{c}\text { Kedalaman } \\
\text { (M) }\end{array}$ & Dabex & Dawagel & & & & \\
\hline 1 & $25 / 06 / 2019$ & B4 & 4 & 6 & 12,0 & 55,0 & 5,0 & 6.842 & 17.280 & 39.744 & 0,41 \\
\hline 2 & $26 / 06 / 2019$ & B4 & 3 & 4 & 8,0 & 9,0 & 7,0 & 954 & 1.536 & 3.533 & 0,71 \\
\hline 3 & $27 / 06 / 2019$ & B8 & 4 & 5 & 5,5 & 95,0 & 15,0 & 3.939 & 12.100 & 27.830 & 0,39 \\
\hline 4 & $28 / 06 / 2019$ & B4 Utara & 4 & 6 & 10,5 & 32,0 & 10,0 & 3.848 & 10.584 & 24.343 & 0,39 \\
\hline 5 & 01/07/2019 & B8 Utara & 4 & 5 & 6,0 & 110,0 & 15,0 & 5.231 & 15.000 & 34.500 & 0,41 \\
\hline 6 & 03/07/2019 & B4 Tengah & 4 & 6 & 11,0 & 37,0 & 10,0 & 4.609 & 12.408 & 28.538 & 0,40 \\
\hline 7 & $04 / 07 / 2019$ & B5 Tengah & 4 & 6 & 11,0 & 72,0 & 7,0 & 8.050 & 20.856 & 47.969 & 0,40 \\
\hline 8 & 05/07/2019 & B4 Tengah & 4 & 6 & 11,0 & 63,0 & 9,0 & 7.256 & 19.008 & 43.718 & 0,40 \\
\hline 9 & 09/07/2019 & B8 & 4 & 6 & 11,0 & 36,0 & 7,0 & 4.283 & 13.200 & 30.360 & 0,40 \\
\hline 10 & $10 / 07 / 2019$ & B4 Timur & 4 & 6 & 10,5 & 50,0 & 10,0 & 5.621 & 15.120 & 34.776 & 0,39 \\
\hline 11 & $11 / 07 / 2019$ & B4 Selatan & 4 & 6 & 11,3 & 39,0 & 10,0 & 4.980 & 15.440 & 35.512 & 0,40 \\
\hline 12 & $12 / 07 / 2019$ & B4 Tengah & 4 & 6 & 10,4 & 27,0 & 20,0 & 4.009 & 11.743 & 27.009 & 0,39 \\
\hline 13 & $15 / 07 / 2019$ & B4 Utara & 4 & 6 & 12,0 & 40,0 & 23,0 & 6.564 & 18.144 & 41.731 & 0,41 \\
\hline 14 & $16 / 07 / 2019$ & B5 Barat & 3 & 4 & 6,0 & 47,0 & 33,0 & 3.107 & 5.760 & 13.248 & 0,68 \\
\hline 15 & $17 / 07 / 2019$ & B4 & 4 & 6 & 12,0 & 53,0 & 37,0 & 9.232 & 25.920 & 59.616 & 0,41 \\
\hline
\end{tabular}

\section{J. DAMPAK PELEDAKAN APLIKASI PRODUK BARU}

Indikator perfomansi bahan peledak selain secara mutu produk dan hasil fragmentasi serta control lemparan yang terkendali tentu harus memperhitungkan aspek dampak dari penggunaan jenis bahan peledak baru tersebut terhadap lingkungan. Selama proses penelitian dilakukan pengukuruan getaran dan noise sebanyak 16 kali menggunakan alat Micromate ${ }^{\mathrm{TM}} \mathrm{SN}$ : UM6451, dengan hasil pada Tabel 4.

Tabel 4. Data pengukuran Micromate ${ }^{\mathrm{TM}}$

\begin{tabular}{|c|c|c|c|c|c|c|}
\hline \multirow[b]{2}{*}{ No } & \multirow[b]{2}{*}{ Tanggal } & \multirow[b]{2}{*}{ Lokasi } & \multicolumn{2}{|c|}{ Ground Vibration } & \multirow{2}{*}{$\begin{array}{l}\text { Air Blast } \\
\text { (dBL) }\end{array}$} & \multirow{2}{*}{$\begin{array}{l}\text { Jarak } \\
\text { (m) }\end{array}$} \\
\hline & & & $\begin{array}{c}\mathrm{PPV} \\
(\mathrm{mm} / \mathrm{s})\end{array}$ & $\begin{array}{c}\text { PVS } \\
(\mathrm{mm} / \mathrm{s})\end{array}$ & & \\
\hline 1 & $25 / 06 / 2019$ & B4 & 0,44 & 0,53 & 121,5 & 400 \\
\hline 2 & $26 / 06 / 2019$ & B4 & 1,84 & 1,88 & 124,0 & 450 \\
\hline 3 & $27 / 06 / 2019$ & B8 & 0,54 & 0,63 & 122,6 & 500 \\
\hline 4 & $28 / 06 / 2019$ & B4 Utara & 0,41 & 0,48 & 127,0 & 500 \\
\hline 5 & $01 / 07 / 2019$ & B8 Utara & 0,47 & 0,53 & 135,0 & 600 \\
\hline 6 & 03/07/2019 & B4 Tengah & 0,44 & 0,49 & 125,0 & 700 \\
\hline 7 & $10 / 07 / 2019$ & B4 Timur & 0,36 & 0,45 & 122,0 & 700 \\
\hline 8 & $11 / 07 / 2019$ & B4 Selatan & 0,48 & 0,52 & 145,0 & 600 \\
\hline 9 & $12 / 07 / 2019$ & B4 Tengah & 0,46 & 0,51 & 141,2 & 500 \\
\hline 10 & $15 / 07 / 2019$ & B4 Utara & 0,47 & 0,56 & 143,3 & 400 \\
\hline 11 & $16 / 07 / 2019$ & B5 Barat & 0,54 & 0,62 & 146,3 & 400 \\
\hline 12 & $17 / 07 / 2019$ & B4 & 0,45 & 0,52 & 135,0 & 500 \\
\hline
\end{tabular}

Hasil monitoring dampak peledakan menunjukkan PVS terbesar di $1,88 \mathrm{~mm} / \mathrm{s}$ pada jarak pengamatan $450 \mathrm{~m}$ tetapi itu juga hanya terjadi satu kali sedangkan rata-rata selama proses penelitian adalah $0,61 \mathrm{~mm} / \mathrm{s}$ dengan rata-rata jarak pengamatan di $534 \mathrm{~m}$. Dengan besaran dampak 
sesuai data terukur tersebut maka secara dampak getaran akibat peledakan masih sangat aman bahkan untuk kategori bangunan Kelas 1 (SNI 7571:2010).

Air blast pressure yang terukur paling tinggi 146,3 dB (L) atau 106,3 dB (A) pada jarak 400 meter. Nilai ini masih berada dibawah nilai ambang batas aman $110 \mathrm{~dB}(\mathrm{~A})$ berdasar rujukan SNI 7570:2010.

\section{K. ANALISA KEEKONOMISAN PRODUK DAWAGEL}

Secara aktual ada penyesuaian (penurunan) Cost Rp/Ton Batu Kapur sebesar IDR 233 (dari hasil 15 kali aplikasi mix dabex 73 \& dawagel), atau setara IDR 114 Juta, dengan hitungan produksi peledakan batu kapur dalam rentang waktu penelitian sebesar 492.429 ton (15 kali peledakan Dawagel+Dabex 73).

Tabel 5. Data komparasi biaya peledakan

\begin{tabular}{|c|c|c|c|c|c|c|c|c|c|c|c|c|}
\hline \multicolumn{7}{|c|}{ APLIKASI PENGGUNAAN DABEX 73 (SINGLE PRODUK) } & \multicolumn{6}{|c|}{ APLIKASI ACTUAL PENGGUNAAN DAWAGEL + DABEX 73 (DOUBLE PRODUK) } \\
\hline No & Jenis Handak & Penggunaan & Harga & Total Harga & Volume (Ton) & Rp/ton & Jenis Handak & Penggunaan & Harga & Total Harga & Volume (Ton) & Rp/ton \\
\hline 1 & Emulsion $(\mathrm{kg})$ & 61.294 & Rp13.160 & Rp806.630.356 & 492.429 & Rp1.638,1 & Emulsion+Dwgl (kg) & 53.604 & Rp13.160 & Rp705.427.324 & 492.429 & Rp $1.432,5$ \\
\hline 2 & Amonium Nitrate (kg) & 26.269 & Rp10.100 & Rp265.315.890 & 492.429 & Rp538,8 & Amonium Nitrate $(\mathrm{kg})$ & 24.923 & Rp10.100 & Rp251.723.310 & 492.429 & Rp511,2 \\
\hline 3 & Inhole Delay (pcs) & 998 & Rp47.950 & Rp47.854.100 & 492.429 & Rpg7,2 & Inhole Delay (pcs) & 998 & Rp47.950 & Rp47.854.100 & 492.429 & Rpg7,2 \\
\hline 4 & Surface Delay (pcs) & 997 & Rp40.793 & Rp40.670.621 & 492.429 & Rp 82,6 & Surface Delay (pcs) & 997 & Rp40.793 & Rp 40.670.621 & 492.429 & Rp 82,6 \\
\hline 5 & Eldeto (pcs) & 15 & Rp14.522 & Rp217.830 & 492.429 & $\mathrm{Rp} 0,4$ & Eldeto (pcs) & 15 & Rp14.522 & Rp217.830 & 492.429 & RpO,4 \\
\hline 6 & Booster (kg) & 199,6 & Rp273.125 & Rp54.515.750 & 492.429 & Rp110,7 & Booster (kg) & 199,6 & Rp273.125 & Rp54.515.750 & 492.429 & Rp 110,7 \\
\hline \multicolumn{6}{|c|}{ Total Rupiah/Ton Batu Kapur } & Rp2.467,8 & \multicolumn{5}{|c|}{ Total Rupiah/Ton Batu Kapur } & Rp2.234,7 \\
\hline
\end{tabular}

Secara bertahap aplikasi Dawagel terus di tingkatkan penggunaanya di lokasi penelitian, dan dalam perkembangannya produk Dawagel akan mampu menekan biaya peledakan turun hingga $25 \%$, ditambah lagi secara kesuluruhan dengan adanya hasil fragmentasi yang baik maka akan menurunkan biaya penambangan hingga ke downstream proses.

\section{KESIMPULAN}

- Kondisi geologi adalah faktor dominan yang menentukan performance peledakan (ISEE Blaster Handbook $18^{\text {th }}$ Edition), sehingga hal ini cukup kuat menjadi dasar dalam rekayasa bahan peledak sebagai salah satu pendekatan untuk mengatasi kondisi geologi tertentu agar bisa tetap menjaga performansi hasil secara optimal.

- Produk Dawagel telah terbukti memiliki kestabilan kimia yang baik, dalam proses produksi, pengangkutan, peyimpanan hingga penerapan dilapangan.

- Penerapan densitas Dawagel antara 0,6-0,8 gr/cc telah menghasilkan VOD $3600-4128 \mathrm{~m} / \mathrm{s}$ dari produk yang sesuai dengan tingkat kekerasan batuan limestone.

- Struktur geologi kompleks pada pada range tertentu telah berhasil diatasi dengan ikatan kimia dari campuran ANFO dengan Dawagel terlihat dengan adanya peningkatan yang baik dari hasil fragmentasi peledakan.

- Penggunaan produk Dawagel akan menggiring kepada penurunan konsumsi AN yang merupakan komposisi Utama dalam campuran isian Utama bahan peledak sehingga akan menurunkan biaya peledakan secara signifikan hingga IDR 114.000.000, -

- MMT dan OSP teknologi yang sudah eksisting terbukti sudah kompatible dengan jenis bahan peledak Dawagel. 


\section{DAFTAR PUSTAKA}

A.P. Thomas (2019). General Report Aplikasi Dawagel (Dabex73C) On Site Semen Tonasa, PT. Dahana Persero; Div. Kuari \& Konstruksi; Site Project Tonasa, Pangkep, Sulawesi Selatan, Indonesia.

A.M. Imran, M Farida, M.F. Arifin \& R Husain (2015). Pleistocene Coral Reef Facies in Bira South Sulawesi. Geological Department, Hasanudin University, Makasar, Indonesia.

Bhandari, Sushil (1997), Engineering Rock Blasting Operation. Departemen of Mining Engineering. JNV University, Jodhpur, India.

Dowling CH (1985), Blast Vibration Monitoring and Control. Englewoods Cliffs, NJ: PrenticeHall.

Golkhale, B.V. (2010), Rotary Drilling and Blasting in Large Surface Mines. CRC Press, London.

Galid, Laraebi (2017), Karakterisasi Kandungan Mineral dan Unsur Penyusun Batu Gamping Pada PT. Semen Tonasa. Fakultas Sains dan Teknologi, UIN Alauddin Makassar; Indonesia.

ISEE. (2011), Blasters' Handbook 18th Edition, International Sosiety of Explosives Engineering. Ohio, USA.

Konya CJ., Walter Edward (1990). Surface Blast Design. Englewoods Cliffs, NJ: Prentice-Hall.

Marmer, Dwihandoyo (2008), Dampak Peledakan. Pusdiklat Teknologi Mineral dan Batubara, Bandung.

MEJ Wilson \& DWJ Bosence (2016), Platform-top and ramp deposit of The Tonasa Carbonate Platform, Sulawesi, Indonesia. SE Asia Research Group London University, Geology Department, Royal Holloway University of London, Egham, Surrey TW 20 0EX, UK.

PT. Dahana Persero (2019) Laporan Aplikasi Dabex 7030C On Site Semen Tonasa. Energetic

Material Centre, Subang, Indonesia.

PT. Semen Indonesia (2017) Laporan berkelanjutan 2017.

Pusdiklat Teknologi Mineral Dan Batubara (2004), Kursus Juru Ledak 2. Bandung.

Standar Nasional Indonesia 7571 (2010), Baku Tingkat Getaran Peledakan Pada Tambang, Terbuka Terhadap Bangunan, Jakarta. 
